\title{
Analysis of Major Nutritional Components of Pleurotus pulmonarius During the Cultivation in Different Indoor Environmental Conditions on Sawdust
}

\author{
Tariqul Islam $^{1}$, Zarina Zakaria ${ }^{2 *}$, Nasrul Hamidin ${ }^{3}$, Mohd Azlan Bin Mohd Ishak ${ }^{4}$ \\ ${ }^{1}$ School of Bioprocess Engineering, Universiti Malaysia Perlis (UniMAP), 02600 Arau, Perlis, Malaysia. \\ ${ }^{2}$ Faculty of Engineering Technology, Universiti Malaysia Perlis (UniMAP), 02100 Padang Besar, Perlis, Malaysia. \\ ${ }^{3}$ School of Environmental Engineering, Universiti Malaysia Perlis (UniMAP), 02600 Arau, Perlis, Malaysia. \\ ${ }^{4}$ Faculty of Applied Sciences, Universiti Technology MARA (UiTM), 02600 Arau, Perlis, Malaysia \\ A R T I C LE IN F O \\ Research Article \\ Received 30 September 2016 \\ Accepted 02 December 2016 \\ Keywords: \\ Indoor \\ Nutritional \\ Mushroom \\ Environment \\ Cultivation \\ *Corresponding Author: \\ E-mail: zarinaz@unimap.edu.my \\ A B S T R A C T \\ Pleurotus pulmonarius was cultivated in three different environmental conditions, in \\ ambient indoor environment (System 1), in humidifying without ventilation (System 2) \\ and in humidifying with ventilation (System 3 ) to analyse the major nutritional contents. \\ Sawdust was the main substrate for all the cultivation systems. The lowest temperature \\ and the highest optimal humidity were found in System 3. The temperature and humidity \\ had shown statistically significant among the three cultivation Systems. The highest \\ numbers of flushes was found both in System 2 and System 3 but System 1 was produced \\ mushrooms till $3^{\text {rd }}$ flush. About $29.5 \%, 28.3 \%, 28.5 \%$ protein; $59.0 \%, 55.8 \%, 54.3 \%$ \\ carbohydrate and 3.8\%, 3.5\%, 3.3\% lipid were found in System 1, System 2 and System \\ 3 respectively. The protein, carbohydrate, and lipid contents were shown statistically \\ insignificant among the cultivation systems. The highest value of protein, carbohydrate \\ and lipid were found for the sample of $1^{\text {st }}$ flush in all the cultivation systems but the \\ values were started to decrease with the increased numbers of flushes significantly. So, \\ this study shown that, although the environmental conditions of the three cultivation \\ systems were varied significantly but the protein, carbohydrate and lipid contents were \\ existed their normal values in all cases but the values were decreased by the increased \\ numbers of flushes.
}

\section{Introduction}

Mushrooms of Pleurotus spp. are commonly known as oyster mushrooms which occupy the second position among most cultivated edible mushrooms worldwide due to their nutritional values (Khan et al., 2008), grow in the wild in tropical and subtropical regions and are easily artificially cultivated (Akindahunsi and Oyetayo, 2006; Chirinang and Intarapichet, 2009). Mushrooms with their flavour, texture, nutritional value and high productivity per unit area have been identified as an excellent food source to alleviate malnutrition in developing countries (Ma et al., 2014; Sufer et al., 2016). Edible mushrooms are highly nutritious and can be compared with eggs, milk and meat (Khatun et al., 2015; Oei, 2003). P. ostreatus, $P$. sajor caju, $P$. florida and Calocybe indica were rich in proteins $(20-25 \%)$ and fibers (13-24\%), lipid (4-5\%), carbohydrate (37 to $48 \%$ ) and ash $(8-13 \%)$. The moisture content of mushrooms were ranged from 86 to $87.5 \%$ (Alam et al., 2008).

$P$. sajor caju was cultivated in $25-30^{\circ} \mathrm{C}$ temperature and $70-80 \%$ relative humidity environmental conditions and found $90 \%$ moisture, $29.3 \%$ protein, $62.9 \%$ carbohydrate, $0.9 \%$ fat and other nutritional components (Gogavekar et al., 2014). Ashraf et al. (2013) studied about the effect of three different substrates (a) cotton waste (b) wheat straw and (c) paddy straw on the nutritive value of three different Pleurotus spp viz $P$. sajor-caju, $P$. ostreatus and $P$. djmor and nutritive contents of $P$. sajorcaju were found high in cotton waste substrate.

In another study, $P$. sajor-cajui was cultivated in four types of substrates (a) paddy straw (b) cotton waste (c) cotton waste with straw and (d) cotton waste with used tea-leaves and compared the nutritional value with Agaricus bisporus, Lentinus edodes, P. ostreatus and Volvariella volvacea. In that study researchers found that $P$. sajor-caju grown on cotton waste as substrate had higher protein content and comparable carbohydrate content to the four common types of mushrooms. The crude fats, ash, energy value, vitamin and mineral contents are lower and yet the differences are not great (Chang et al., 1981). Ganoderma lucidum grown on orange stump had higher nutritional value than mushrooms collected from nature (Turfan et al., 2016).

Presently sawdust is commonly used and is preferred medium at commercial scale. Different spawn of oyster mushroom was cultivated on sawdust as the fastest spawn running, pinhead formation, the highest mean yield and 
maximum fresh yield percentage (Pathmashini et al., 2009). Very little study has performed on mushrooms nutritional contents by harvesting flushes and different environmental conditions. So, this study has initiated to investigate and analyse the major nutritional contents of $P$. pulmonarius (protein, carbohydrate and lipid) cultivated in different environmental conditions on sawdust as the main substrate.

\section{Materials and Methods}

\section{Preparation of Mushroom Growing Bags}

Substrates for growing mushroom bags were formulated by the mixture of saw-dust, rice bran and agricultural lime with the ratio of 100:10:1 (Abdul et al., 2011). About $800 \mathrm{~g}$ of substrate mixtures was filled in each autoclavable polypropylene bags $(6 \times 9$ inch $)$ and then the opening parts of the bags were closed by plastic cork, paper, rubber band and cap to protect loss of moisture content from inside the bags (Islam et al., 2016b). After that, the bags were sterilized at 20 psi pressure and $121^{\circ} \mathrm{C}$ temperatures for 6 hours to kill the spore of bacteria, fungi and other microorganisms (Christopher and Custodio, 2004). After sterilization, they were cooled to room temperature and injected with spawn prepared through tissue culture technique in Cell and Tissue Culture Laboratory, University Malaysia Perlis. Then the spawn injected bags were then placed vertically for 30-35 days in the dark for mycelium colonization.

\section{Indoor Mushroom Cultivation}

The experimental procedures were designed as ambient indoor environment without humidifying and ventilation (System 1), indoor humidifying environment without ventilation (System 2), indoor humidifying environment with ventilation (System 3) and indoor ventilating environment without humidifier (System 4). System 4 had no longer performed as in Malaysian environment where the indoor humidity is too low. Therefore, ventilation treatment absorbs the indoor humidity and tends to reduce it severely. In this condition, without any humidifying system mushrooms are not able to grow in Malaysia. So, this study had performed mushroom cultivation in System 1, System 2 and System 3.

The complete colonization 200 bags were transferred into the indoor growing room and arranged by rope as Islam et al., (2016a) for System 1, System 2 and System 3 consecutively. Four units of thermohygrometer were installed in different points to monitor and record the temperature and humidity.

No artificial method was applied during the cultivation of System 1 but System 2 and System 3 were followed in optimum humidity $80-90 \%$ by humidifier and ventilation (for System 3). For System 2, the humidifier was controlled by fixing with timer at 20 minutes running followed by 65 minutes interval to retain $80-90 \%$ humidity. And for System 3, the humidifier was controlled by fixing with timer at 25 minutes running followed by 35 minutes interval to retain $80-90 \%$ humidity. These humidifying durations were optimized by the optimization procedure (Islam et al., 2016b, 2016c). The temperature and humidity inside the indoor growing house were monitored and recorded by every hour. After maturation, the fruit bodies were harvested for nutritional analysis.

\section{Mushroom Sample Preparation}

About $500 \mathrm{~g}$ of the first flush fresh mushrooms from "System 1"-, -"System 2"- and -"System 3"- were collected from the cultivation room. After that, they were transferred to biochemistry laboratory of University Malaysia Perlis (UniMAP) to follow the next procedures. The mushroom samples were placed in the laboratory oven for 3 hours at $50^{\circ} \mathrm{C}$ to remove all the water content without denaturation and degradation of protein. After 3 hours, the dried mushrooms were removed from the laboratory oven and weighed on digital weighing machine. Then, they were grinded in a grinder for 2 to 3 minutes at high speed in order to obtain mushrooms in powder form. Transparent plastic bags were used to keep the powdered mushrooms for biochemical analysis. This process was repeated for the intermediate and last flush of production as Table 1. This sample preparation procedure was followed by the extraction technique (Mizuno, 1995). In Table 1 , sample of $1^{\text {st }}$ and $3^{\text {rd }}$ flush was collected from System 1 since no mushroom was found after $3^{\text {rd }}$ flush of harvesting in this cultivation system.

Table 1 Sample collection from different cultivation systems for biochemical analysis

\begin{tabular}{c|ccc}
\hline System & Sample 1 & Sample 2 & Sample 3 \\
\hline System 1 & $1^{\text {st }}$ Flush & $3^{\text {rd }}$ Flush & \\
System 2 & $1^{\text {st }}$ Flush & $4^{\text {th }}$ Flush & $7^{\text {th }}$ Flush \\
System 3 & $1^{\text {st }}$ Flush & $4^{\text {th }}$ Flush & $7^{\text {th }}$ Flush \\
\hline
\end{tabular}

\section{Determination of Total Protein}

Preparation of protein standard curve: Total $200 \mathrm{mg}$ of Bovine Serum Albumin (BSA) powder was dissolved in $100 \mathrm{ml}$ distilled water and stirred to produce $2 \mathrm{mg} / \mathrm{ml}$ or $0.2 \%$ BSA stock solution. Then, $0.5 \mathrm{ml}$ of BSA stock solution was pipetted into the test tube and distilled water was added to make up $5 \mathrm{ml}$ total solution so that 0.2 $\mathrm{mg} / \mathrm{ml}$ BSA concentration solution was made. This process was repeated for $0.4 \mathrm{mg} / \mathrm{ml}, 0.6 \mathrm{mg} / \mathrm{ml}, 0.8$ $\mathrm{mg} / \mathrm{ml}, 1.0 \mathrm{mg} / \mathrm{ml}, 1.2 \mathrm{mg} / \mathrm{ml}, 1.4 \mathrm{mg} / \mathrm{ml}, 1.6 \mathrm{mg} / \mathrm{ml}, 1.8$ $\mathrm{mg} / \mathrm{ml}$ and $2.0 \mathrm{mg} / \mathrm{ml}$ by increasing $0.5 \mathrm{ml} \mathrm{BSA}$ stock solution and reducing $0.5 \mathrm{ml}$ distilled water one after another. Then, $5.0 \mathrm{ml}$ analytical reagent $(100 \mathrm{ml}$ of sodium carbonate $\left(\mathrm{Na}_{2} \mathrm{CO}_{3}\right)$ and $\mathrm{NaOH}$ mixture, $2 \mathrm{ml}$ of copper sulphate $\left(\mathrm{CuSO}_{4}\right)$ solution and sodium potassium tartrate $\left(\mathrm{KNaC}_{4} \mathrm{H}_{4} \mathrm{O}_{6}\right)$ mixture $)$ was added to each different BSA concentration solution. The mixtures were left at room temperature for 10 minutes to react. Next, 0.2 $\mathrm{ml} 50 \%(\mathrm{v} / \mathrm{v})$ Folin-Ciocalteau phenol test solution was added into respective test tubes to react for another 30 minutes. After that, BSA concentration was measured using spectrophotometer at wavelength of $660 \mathrm{~nm}$. Lastly, a graph was plotted using BSA concentration on the $\mathrm{X}$ axis while the absorbance value on the $\mathrm{Y}$-axis. 
Total protein analysis: The protein concentration was analysed using Lowry's method (Lowry et al., 1951). About $10 \mathrm{mg}$ of mushroom powder of each flush from "System 1"- were weighed into different test tubes and 5 $\mathrm{ml}$ of $1 \mathrm{~N}(\mathrm{NaOH})$ was added. The test tubes were kept at room temperature for 24 to 48 hours for protein extraction. After 24 to 48 hours of extraction, the samples were centrifuged at 5,000 rpm for 10 minutes and $0.5 \mathrm{ml}$ of each protein extract was pipetted into the test tubes containing $5 \mathrm{ml}$ of analytical reagent and allowed to incubate at room temperature for 10 minutes. After 10 minutes of incubation, $0.5 \mathrm{ml}$ of $1 \mathrm{~N}$ Folin-Ciocalteau phenol test solution was added into each test tube and incubated for another 30 minutes. $3 \mathrm{ml}$ of sample from each test tube was pipetted into cuvettes for absorbance testing. The absorbance was determined at $660 \mathrm{~nm}$ using spectrophotometer and set to zero using blank sample. Concentration of protein for each sample was determined using the same procedure. This same procedure was repeated for the samples of -"System 2"- and -"System 3"- as in Table 1. All this process was triplicate for ANOVA.

\section{Determination of Total Carbohydrate}

Preparation of glucose standard curve: Total $100 \mathrm{mg}$ of glucose was dissolved in $100 \mathrm{~mL}$ of water as stock solution. $10 \mathrm{~mL}$ of stock solution was diluted to $100 \mathrm{~mL}$ with distilled water to produce $0.1 \mathrm{mg} / \mathrm{ml}$ working standard solution. Then $0.2,0.4,0.6,0.8$ and $1 \mathrm{ml}$ of working standard of glucose was taken in boiling tubes and the final volumes of each tube was made $1 \mathrm{ml}$ by adding distilled water. $1 \mathrm{ml}$ of $5 \%$ phenol and $5 \mathrm{ml}$ of $96 \%$ sulphuric acid was added one by one in each tube and shook well so that the phenol and sulphuric acid get mixed thoroughly with working standard. After 10 minutes all the tubes were placed in water bath at 25 $30^{\circ} \mathrm{C}$ for 15 minutes. Blank was set with $1 \mathrm{ml}$ of distilled water and optical density of each tube was taken at 490 nm using spectrophotometer. Finally, a graph was plotted using glucose concentration on the $\mathrm{X}$-axis while the absorbance value on the $\mathrm{Y}$-axis.

Total carbohydrate analysis: The carbohydrate concentration was analysed using phenol sulphuric acid method (DuBois et al., 1956). About $100 \mathrm{mg}$ of mushroom powder from each sample of -"System 1"- was added with $5 \mathrm{ml}$ of $2.5 \mathrm{~N}$ hydrochloric acid and put into boiling water for about 3 hours. After that the samples were being cooled at room temperature before being neutralized with solid sodium carbonate until effervescence ceases. The volume of each sample had been made as $100 \mathrm{ml}$ and centrifuged. Then, $0.2 \mathrm{ml}$ of sample solution from each centrifuged sample was pipette out and transferred to a test tube. After that, $0.8 \mathrm{ml}$ of distilled water was added to each test tube until it reaches $1 \mathrm{ml} .1 \mathrm{ml}$ of phenol solution and $5 \mathrm{ml}$ of $96 \%$ of sulphuric acid were added to each of the test tube and shaken thoroughly with the use of vortex. After 10 minutes of shaken, the test tubes was then placed into a water bath at $25-30{ }^{\circ} \mathrm{C}$ for 20 minutes before being read at uv-spectrometer at $490 \mathrm{~nm}$ wavelength to record optical density. This same procedure was repeated for the samples of -"System 2"- and -"System 3"- as in Table 1. All this process was triplicate for ANOVA.

Determination of total fat: Total lipid was determined by slight modified of Folch method (Folch et al., 1957). 5 $\mathrm{g}$ of ground mushroom powder from each sample of "System 1"- was suspended in $50 \mathrm{ml}$ of chloroform: methanol $(2: 1 \mathrm{v} / \mathrm{v})$ mixture then mixed thoroughly and incubated for three days. The solution was filtrated and centrifuged at $1000 \times \mathrm{g}$ by a table centrifuge machine. The upper layer of methanol was removed by Pasteur pipette and chloroform was evaporated by heating. The remaining was the crude lipid. This same procedure was repeated for the samples of -"System 2"- and -"System 3"- as in Table 1. All this process was triplicate for ANOVA.

\section{Results and Discussion}

\section{Indoor Environment}

The temperature and relative humidity persisting in all experimental methods inside the rooms are presented in Table 2a. Maximum, minimum and mean temperatures were varied greatly among the three different cultivation methods. The lowest mean temperature of $27.5 \pm .6^{\circ} \mathrm{C}$ and the highest mean humidity of $89.1 \pm 2.9 \%$ were observed in System 3 whereas the highest temperature of $30.1 \pm .9^{\circ} \mathrm{C}$ and the lowest mean humidity of $64.4 \pm 8.7 \%$ were observed in System 1. The mean temperature of System 2 was $28.9 \pm .7^{\circ} \mathrm{C}$ which was lower than System-1 but higher compared to System 3. Whereas the mean humidity of System-2 was $84.3 \pm 3.6 \%$ which was higher than System 1 but also lower than System 3 (Table 2a). The overall mean temperature and humidity were shown significantly difference in one-way ANOVA where the significance level was $\mathrm{P}<0.05$ (Table $2 \mathrm{~b}$ ).

Table 2a Descriptive statistics of temperature and humidity in different environmental conditions during cultivation

\begin{tabular}{c|cccccc}
\hline Parameter & Environmental Conditions & Mean & Std. Deviation & Std. Error & Minimum & Maximum \\
\hline \multirow{3}{*}{ Temperature } & System 1 & 30.1 & 0.89 & 0.063 & 29.00 & 32.00 \\
& System 2 & 28.9 & 0.69 & 0.048 & 28.00 & 30.00 \\
& System 3 & 27.5 & 0.64 & 0.032 & 26.50 & 29.50 \\
\hline \multirow{3}{*}{ Humidity } & System 1 & 64.39 & 8.74 & 0.618 & 41.00 & 77.00 \\
& System 2 & 84.22 & 3.61 & 0.255 & 80.00 & 90.00 \\
& System 3 & 89.06 & 2.91 & 0.145 & 80.00 & 90.00 \\
\hline
\end{tabular}


Table $2 b$ One way ANOVA of temperature and humidity in different environmental conditions during cultivation

\begin{tabular}{c|cccccc}
\hline Parameter & Compare & Sum of Squares & Df & Mean Square & F & Sig. \\
\hline \multirow{2}{*}{ Temperature } & Between Groups & 861.4 & 2 & 430.7 & \multirow{2}{*}{822.8} & \multirow{2}{*}{0.000} \\
& Within Groups & 417.2 & 797 & .52 & & \multirow{2}{*}{0.000} \\
\hline \multirow{2}{*}{ Humidity } & Between Groups & 82819.7 & 2 & 41409.9 & 26.5 & \multirow{2}{*}{0.8} \\
& Within Groups & 21132.1 & 797 & 26.5 & \\
\hline
\end{tabular}

\section{Total Protein Analysis}

Protein standard calibration curve analysis: The standard curve of protein was used as the calibration curve for total protein content in the sample. A graph of absorbance reading at $660 \mathrm{~nm}$ against protein concentration was plotted. The standard curve equation obtained was as equation (1) with the correlation coefficient, $\mathrm{R}^{2}$ of 0.997 .

$$
y=1.597 x
$$

Where $y$ is the absorbance reading at $660 \mathrm{~nm}$ and $\mathrm{x}$ is protein concentration $(\mathrm{mg} / \mathrm{ml})$. Figure 1 shows the bovine serum albumin (BSA) standard curve.

Protein content in different cultivation systems: The protein content of $30.58 \pm 0.07 \%, 30.66 \pm 0.19 \%$ and $30.73 \pm 0.14 \%$ were found in the first harvesting flushes of System 1, System 2 and System 3 respectively. Sample 2 was collected from $3^{\text {rd }}$ flush of System 1 and $4^{\text {th }}$ flush of System 2 and System 3 since System 1 was not produced mushroom after $3^{\text {rd }}$ harvesting flushes due to unfavourable environmental conditions. The protein content of sample 2 was found as $28.48 \pm 0.2 \%$, $28.63 \pm 0.23 \%$ and $29.23 \pm 0.25 \%$ in System 1, System 2 and System 3 respectively. The sample 3 was collected from the $7^{\text {th }}$ harvesting flushes of System 2 and System 3, the protein content was found $25.85 \pm 0.16 \%$ and $25.66 \pm 0.14 \%$ in the System 2 and System 3 respectively (Table 3). So, this result showed that the percentage of protein content of $P$. pulmonarius was decreased with the increased numbers of harvesting flush.

The overall $29.53 \pm 1.05 \%, \quad 28.38 \pm 1.39 \% \quad$ and $28.54 \pm 1.51 \%$ protein had found in System 1, System 2 and System 3 respectively. The mean value of System 1 was found as the highest protein content since the sample was collected only from $1^{\text {st }}$ and $3^{\text {rd }}$ harvesting flush (Table $3)$. The protein content of different flushes had showed statistically significant whereas insignificant result was found at 0.856 levels among the System 1, System 2 and System 3 in one-way ANOVA test where the significant level was considered at $\mathrm{P} \leq 0.05$ (Table 4).

\section{Total Carbohydrate Analysis}

Standard curve calibration analysis: The purpose of standard curve was to obtain the equation which was required in order to calculate the concentration of glucose solution at different conditions. The standard was determined by measuring the absorbance of glucose solution at different concentrations. The wavelength of the absorbance was set at $490 \mathrm{~nm}$. From the reading of the absorbance that had been recorded, the standard curve of glucose concentration versus absorbance was plotted and generated an equation (2).

$$
y=57.5 \times 0.0167
$$

By the equation (2), the absorbance value which was determined at wavelength of $490 \mathrm{~nm}$ was denoted as $\mathrm{y}$ and $\mathrm{x}$ refers to the concentration of glucose. The correlation coefficient, $\mathrm{R}^{2}$ obtained was 0.9902 , which is acceptable as the value closed to 1 (Figure 2). This standard curve equation was used to calculate the concentration of carbohydrate in the samples of this study.

Carbohydrate content in different cultivation systems: The carbohydrate content had found $62.5 \pm 0.432 \%$, $63.0 \pm 0.647 \%$ and $62.5 \pm 0.912 \%$ in the first harvesting flushes of System 1, System 2 and System 3 respectively. Sample 2 was collected from $3^{\text {rd }}$ flush of System 1 and $4^{\text {th }}$ flush of System 2 and System 3 since System 1 had not produced mushroom after $3^{\text {rd }}$ flush because of unfavourable environmental conditions. The carbohydrate content of sample 2 was found $55.5 \pm 0.910 \%$, $56.0 \pm 0.647 \%$ and $54.0 \pm 0.648 \%$ in System 1, System 5 and System 3 respectively. The sample 3 was collected from the $7^{\text {th }}$ flush of System 2 and System 3. The carbohydrate content $48.56 \pm 1.191 \%$ and $46.5 \pm 0.192 \%$ were in sample 3 of System 2 and System 3 respectively (Table 5).

The overall mean value of carbohydrate contents in System 1, System 2 and System 3 had found $29.53 \pm 1.05 \%, \quad 28.38 \pm 1.39 \% \quad$ and $28.54 \pm 1.51 \%$ respectively. The carbohydrate contents of System 1 was also found as the highest carbohydrate content since the sample was collected only from $1^{\text {st }}$ and $3^{\text {rd }}$ harvesting flushes. The carbohydrate content was found statistically significant among the different harvesting flushes where the values were started to decrease by increased number of harvesting flushes. But the overall mean values were found insignificant at 0.783 levels among the System 1, System 2 and System 3 in one-way ANOVA test where the significant level was considered at $\mathrm{P} \leq 0.05$ (Table 6).

\section{Lipid Analysis}

The lipid content of $4.04 \pm 0.104 \%, 4.07 \pm 0.174 \%$ and $4.14 \pm 0.152 \%$ were found in the first flush of System 1, System 2 and System 3 respectively. Sample 2 was collected from $3^{\text {rd }}$ flush of System 1 and $4^{\text {th }}$ flush of System 2 and System 3 since System 1 was not produced mushroom after $3^{\text {rd }}$ flush because of unfavourable environmental conditions. The lipid content of sample 2 was found $3.61 \pm 0.046 \%, 3.58 \pm 0.064 \%$ and $3.3 \pm 0.092 \%$ in System 1, System 2 and System 3 respectively. The sample 3 was collected from the $7^{\text {th }}$ flush of System 2 and System 3. The lipid content of sample 3 was found $2.70 \pm 0.52 \%$ and $2.56 \pm 0.086 \%$ in the case of System 2 and System 3 respectively (Table 7). 


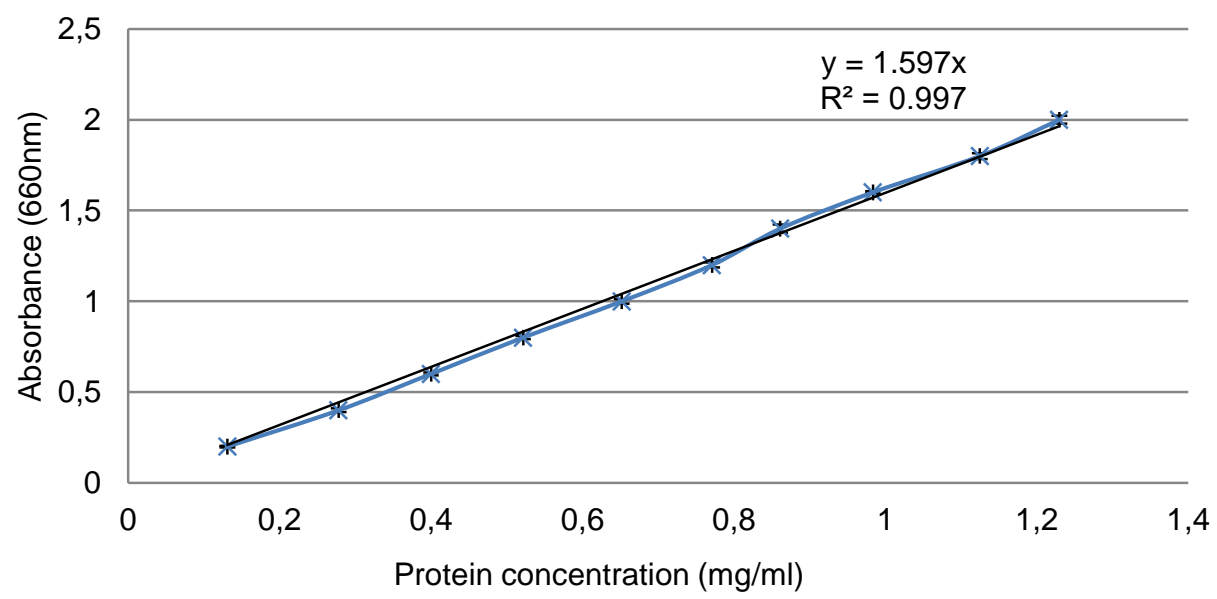

Figure 1 Bovine serum albumin (BSA) standard curve

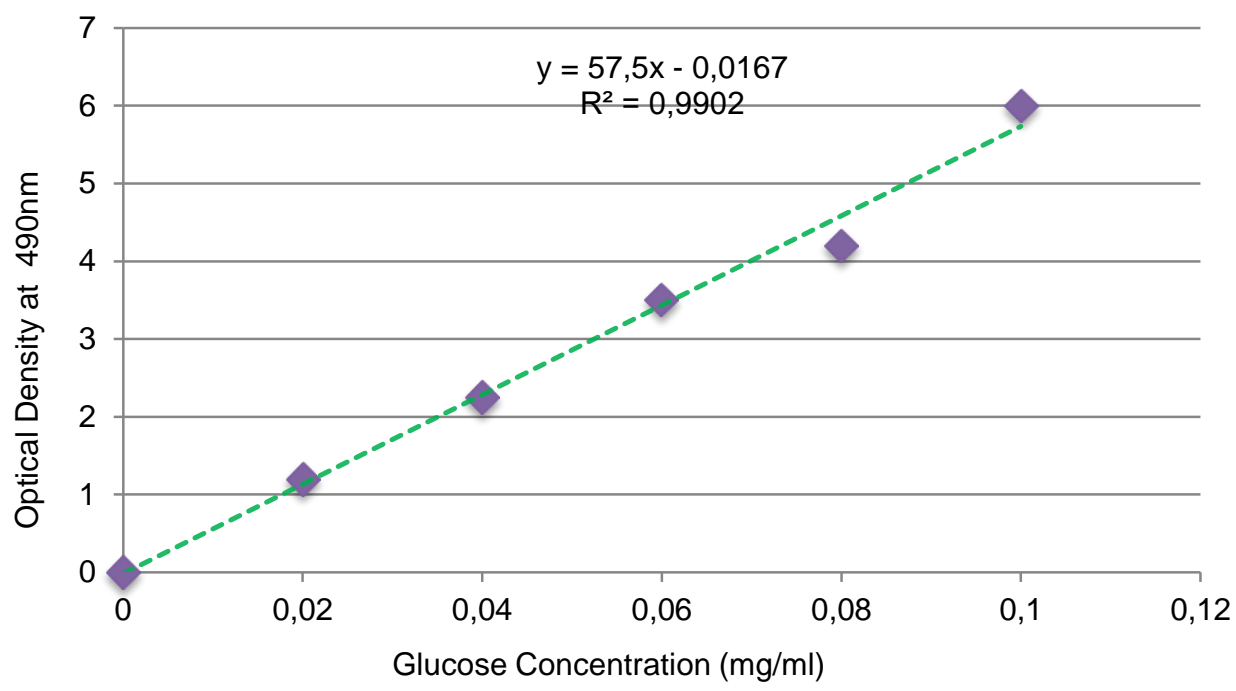

Table 3 Percentages of protein concentration in different cultivation systems and flushes (Dried Sample)

\begin{tabular}{|c|c|c|c|c|c|}
\hline \multirow{2}{*}{ Condition } & \multirow{2}{*}{$\begin{array}{l}\text { Sample } \\
\text { (Flush) }\end{array}$} & \multirow{2}{*}{$\begin{array}{l}\text { Absorbance } \\
\text { Mean } \pm \text { SE }\end{array}$} & \multirow{2}{*}{$\begin{array}{l}\text { Protein concentration } \\
\qquad(\mathrm{mg} / \mathrm{ml})\end{array}$} & \multicolumn{2}{|c|}{ Percentages of Protein Contents (\%) } \\
\hline & & & & Sample Mean \pm SE $(\%)$ & System Mean \pm SE $(\%)$ \\
\hline \multirow{2}{*}{ System 1} & Sample 1 & $0.814 \pm 0.002$ & $0.509 \pm 0.001$ & $30.58 \pm 0.07$ & \multirow{2}{*}{$29.531 \pm 1.05$} \\
\hline & Sample 2 & $0.758 \pm 0.006$ & $0.475 \pm 0.004$ & $28.48 \pm 0.23$ & \\
\hline \multirow{3}{*}{ System 2} & Sample 1 & $0.816 \pm 0.005$ & $0.5110 \pm 0.003$ & $30.66 \pm 0.19$ & \multirow{3}{*}{$28.38 \pm 1.39$} \\
\hline & Sample 2 & $0.762 \pm 0.006$ & $0.477 \pm 0.004$ & $28.63 \pm 0.23$ & \\
\hline & Sample 3 & $0.681 \pm 0.004$ & $0.4264 \pm 0.003$ & $25.85 \pm 0.16$ & \\
\hline \multirow{3}{*}{ System 3} & Sample 1 & $0.818 \pm 0.004$ & $0.5122 \pm 0.002$ & $30.73 \pm 0.14$ & \multirow{3}{*}{$28.54 \pm 1.51$} \\
\hline & Sample 2 & $0.778 \pm 0.007$ & $0.4872 \pm 0.0041$ & $29.23 \pm 0.25$ & \\
\hline & Sample 3 & $0.683 \pm 0.004$ & $0.4277 \pm 0.002$ & $25.66 \pm 0.14$ & \\
\hline
\end{tabular}

The results are the mean \pm SEM of 3 replicates.

Table 4 One-way ANOVA analysis for protein contents of mushroom in different cultivation systems and flushes

\begin{tabular}{|c|c|c|c|c|c|c|}
\hline Factors & Compared & Sum of Squares & Df & Mean Square & $\mathrm{F}$ & Sig. \\
\hline \multirow{3}{*}{ In Flushes } & Between Groups & 28.845 & 2 & 14.422 & \multirow{3}{*}{209.435} & \multirow{3}{*}{0.000} \\
\hline & Within Groups & 344 & 5 & 0.069 & & \\
\hline & Total & 29.189 & 7 & & & \\
\hline \multirow{3}{*}{ In Systems } & Between Groups & 1.759 & 2 & 0.879 & \multirow{3}{*}{0.160} & \multirow{3}{*}{0.856} \\
\hline & Within Groups & 27.438 & 5 & 5.488 & & \\
\hline & Total & 29.197 & 7 & & & \\
\hline
\end{tabular}


Table 5 Percentages of carbohydrate concentration in different cultivation systems and flushes (Dried sample)

\begin{tabular}{|c|c|c|c|c|c|}
\hline \multirow{2}{*}{ Condition } & \multirow{2}{*}{$\begin{array}{l}\text { Sample } \\
\text { (Flush) }\end{array}$} & \multirow{2}{*}{$\begin{array}{l}\text { Absorbance } \\
\text { Mean } \pm \text { SE }\end{array}$} & \multirow{2}{*}{$\begin{array}{c}\text { Carbohydrate } \\
\text { concentration }(\mathrm{mg} / \mathrm{ml})\end{array}$} & \multicolumn{2}{|c|}{ Percentages of Carbohydrate concentration (\%) } \\
\hline & & & & Sample Mean \pm SE $(\%)$ & System Mean \pm Std. \\
\hline \multirow{2}{*}{ System 1} & Sample 1 & $7.13 \pm 0.033$ & $0.125 \pm 0.0009$ & $62.5 \pm 0.432$ & \multirow{2}{*}{$59.00 \pm 4.95$} \\
\hline & Sample 2 & $6.37 \pm 0.088$ & $0.111 \pm 0.0018$ & $55.5 \pm 0.910$ & \\
\hline \multirow{3}{*}{ System 2} & Sample 1 & $7.2 \pm 0.058$ & $0.126 \pm 0.0012$ & $63.0 \pm 0.647$ & \multirow{3}{*}{$55.85 \pm 7.22$} \\
\hline & Sample 2 & $6.4 \pm 0.058$ & $0.112 \pm 0.0012$ & $56.0 \pm 0.647$ & \\
\hline & Sample 3 & $5.57 \pm 0.120$ & $0.097 \pm 0.0024$ & $48.56 \pm 1.191$ & \\
\hline \multirow{3}{*}{ System 3} & Sample 1 & $7.13 \pm 0.088$ & $0.125 \pm 0.0018$ & $62.5 \pm 0.912$ & \multirow{3}{*}{$54.33 \pm 8.01$} \\
\hline & Sample 2 & $6.20 \pm 0.057$ & $0.108 \pm 0.0013$ & $54.0 \pm 0.648$ & \\
\hline & Sample 3 & $5.33 \pm 0.088$ & $0.093 \pm 0.0018$ & $46.5 \pm 0.912$ & \\
\hline
\end{tabular}

The results are the mean \pm SEM of 3 replicates.

Table 6 One-way ANOVA analysis for carbohydrate contents of mushroom in different cultivation systems and flushes

\begin{tabular}{|c|c|c|c|c|c|c|}
\hline Factors & Compared & Sum of Squares & Df & Mean Square & $\mathrm{F}$ & Sig. \\
\hline \multirow{3}{*}{ In Flushes } & Between Groups & 278.859 & 2 & 139.430 & \multirow{3}{*}{156.48} & \multirow{3}{*}{0.000} \\
\hline & Within Groups & 4.455 & 5 & 0.891 & & \\
\hline & Total & 283.314 & 7 & & & \\
\hline \multirow{3}{*}{ In Systems } & Between Groups & 26.359 & 2 & 13.179 & \multirow{3}{*}{0.256} & \multirow{3}{*}{0.783} \\
\hline & Within Groups & 256.956 & 5 & 51.391 & & \\
\hline & Total & 283.314 & 7 & & & \\
\hline
\end{tabular}

Values are significant at $\mathrm{P} \leq 0.05$ level.

Table 7 Percentages of lipid concentration in different cultivation systems and flushes (g/100g Dried Sample)

\begin{tabular}{l|ccc}
\hline \multirow{2}{*}{ Condition } & Sample (Flush) & \multicolumn{2}{c}{ Percentages of Lipid Concentration (g/100g dried sample) } \\
\cline { 2 - 4 } & Sample 1 & Sample Mean \pm SE. & System Mean \pm SE. \\
\hline \multirow{2}{*}{ System 1 } & Sample 2 & $4.04 \pm 0.104$ & $3.83 \pm 0.215$ \\
& Sample 1 & $3.61 \pm 0.046$ & $3.45 \pm 0.401$ \\
\multirow{2}{*}{ System 2 } & Sample 2 & $4.07 \pm 0.174$ & $3.33 \pm 0.791$ \\
& Sample 3 & $3.58 \pm 0.064$ & \\
\hline \multirow{2}{*}{ System 3 } & Sample 1 & $4.70 \pm 0.52$ & $3.14 \pm 0.152$ \\
& Sample 2 & $2.56 \pm 0.092$ & \\
\hline
\end{tabular}

The results are the mean \pm SEM of 3 replicates.

Table 8 One-way ANOVA analysis for lipid contents of mushroom in different cultivation systems and flushes

\begin{tabular}{|c|c|c|c|c|c|c|}
\hline Factors & Compared & Sum of Squares & Df & Mean Square & $\mathrm{F}$ & Sig. \\
\hline \multirow{3}{*}{ In Flushes } & Between Groups & 2.535 & 2 & 1.267 & & \\
\hline & Within Groups & 0.074 & 5 & 0.015 & 86.17 & 0.000 \\
\hline & Total & 2.608 & 7 & & & \\
\hline \multirow{3}{*}{ In Systems } & Between Groups & 0.302 & 2 & 0.151 & & \\
\hline & Within Groups & 2.306 & 5 & 0.461 & 0.327 & 0.735 \\
\hline & Total & 2.608 & 7 & & & \\
\hline
\end{tabular}

Values are significant at $\mathrm{P} \leq 0.05$ level.

The overall mean value of lipid contents of System 1 , System 2 and System 3 were found $3.83 \pm 0.215 \%$, $3.45 \pm 0.401 \%$ and $3.33 \pm 0.791 \%$ respectively. The mean value of System 1 was found as the highest lipid content since the sample was collected only from $1^{\text {st }}$ and $3^{\text {rd }}$ harvesting flushes (Table 7). The protein content had showed statistically significant among the different harvesting flushes whereas insignificant result was found at 0.856 levels among the System 1, System 2 and System 3 in one-way ANOVA test where the significant level had considered at $\mathrm{P} \leq 0.05$ (Table 8).
Within these three systems, the mean temperature varied approximately $1.1-2.5^{\circ} \mathrm{C}$ and the mean humidity varied approximately 19.9-24.7\% which had shown statistically significant results with one-way ANOVA where the significance level was $\mathrm{P}<0.05$ (Table $2 \mathrm{~b}$ ). In System 2, the temperature and humidity varied $1.05^{\circ} \mathrm{C}$ lower and $19.84 \%$ higher from System 1 respectively. Other hand in System 3, the temperature and humidity varied $2.46^{\circ} \mathrm{C}$ lower and $24.66 \%$ higher from System 1 respectively. So the temperature and humidity of System 3 was found $1.41^{\circ} \mathrm{C}$ lower and $4.88 \%$ higher (respectively) than System 2. The lowest indoor 
temperature $\left(26.5^{\circ} \mathrm{C}\right)$ was also found in System 3 whereas; the highest $\left(32^{\circ} \mathrm{C}\right)$ was in System 1. Moreover in System 1 and 2, there was no proper air circulation although the humidity of System 2 was within optimal ranges. This result agrees with Thepa et al. (1999) that evaporative cooling and continuous ventilation system reduced the temperature and increased the relative humidity of air inside a mushroom house, which is also similar to the earlier report of Leiva et al. (2015). So, this result has shown that the environmental conditions of these three cultivation systems were significantly different from each other.

In this study it was noticed that the protein, carbohydrate and lipid contents of $P$. pulmonarius decreased with the increasing number of harvesting flushes. Although the cultivation systems had found significant different environmental condition but the nutritional contents were noticed decreased by increasing flushes in all systems of cultivation. Moreover, System 3 had provided the best environmental condition for mushroom growing but the same results also had found. Caglarırmak (2007) reported that, the nutritional contents of Pleurotus species had significantly decreased by increasing numbers of harvesting which is also supported to the report of Miles and Chang, (2004).

On the other hand, the overall mean value of protein, carbohydrate and lipid had found insignificant difference among the cultivation systems. The significant difference of environment among the systems had influenced the number of flushes and production but not influenced the nutritional contents of protein, carbohydrate and lipid. Kadlag et al. (1998) reported that the protein content of oyster mushroom varied between the ranges of $20 \%$ and $30 \%$ on a dry weight basis in different species. Some other studies also reported that the protein contents of $P$. pulmonarius varied from 25 to $30 \%$ (Ashraf et al., 2013; Gogavekar et al., 2014; Miles and Chang, 2004).Several studies also reported that the carbohydrate contents of $P$. pulmonarius varied from 30 to 50\% (Ashraf et al., 2013; Maria et al., 2015). Very low value (2.5-4.07 g/100g) of lipid content in $P$. pulmonarius was found in this present study. The lipid content usually ranges between 2.6-5.5 $\mathrm{g} / 100 \mathrm{~g}$ among different Pleurotus spp. of oyster mushrooms (Alam et al., 2008; Khan et al., 2008). So, study proved that, the variation of environmental conditions influenced the number of flushes and production of $P$. pulmonarius but the protein, carbohydrate and lipid contents are independent of environment conditions. Therefore, the percentages of protein, carbohydrate and lipid were exit at their normal value cultivated on sawdust as substrate.

\section{Conclusions}

Based on the result of current study, it could be concluded that mushroom is able to be cultivated in controlled environment where the humidifying with ventilation system provided better growing environment than others. In view of different indoor environmental conditions, there was no significant difference had found in protein, carbohydrate and lipid contents which were exit at normal value cultivated on sawdust. But the protein, carbohydrate and lipid contents had found significantly decreasing with increasing numbers of flushes in all the cultivation systems. So, this study concluded that indoor environment can influence the mushrooms flush of harvesting and production but the protein, carbohydrate and lipid contents are independent of environmental conditions.

\section{References}

Abdul A, Rozainee M, Mutahharah M. 2011. Microwave sterilization of mushroom production media. Waste Management and Bioresource Technology, 1(1): 1-11.

Akindahunsi AA, Oyetayo FL. 2006. Nutrient and antinutrient distribution of edible mushroom, Pleurotus tuber-regium (fries) singer. Food Science and Technology, 39(5): 548-553.

Alam N, Amin R, Khan A, Ara I, Shim MJ, Lee MW, Lee TS. 2008. Nutritional analysis of cultivated mushrooms in Bangladesh Pleurotus ostreatus, Pleurotus sajor-caju, Pleurotus florida and Calocybe indica. Mycobiology, 36(4): 228-32.

Ashraf J, Ali MA, Ahmad W, Ayyub CM, Shafi J. 2013. Effect of different substrate supplements on oyster mushroom (Pleurotus spp.) production. Food Science and Technology, 1(3): 44-51.

Caglarırmak N. 2007. The nutrients of exotic mushrooms (Lentinula edodes and Pleurotus species) and an estimated approach to the volatile compounds. Food chemistry, 105(3): 1188-1194.

Chang ST, Lau OW, Cho KY. 1981. The cultivation and nutritional value of Pleurotus sajor-caju. European Journal of Applied Microbiology and Biotechnology, 12(1): 58-62.

Chirinang P, Intarapichet KO. 2009. Amino acids and antioxidant properties of the oyster mushrooms, Pleurotus ostreatus and Pleurotus sajor-caju. Science Asia, 35: 326-331.

Christopher J. Custodio D. 2004. Substrate: Oyster mushroom cultivation. In Mushroom Grower's Handbook 1. China: MushWorld, pp. 91-94.

DuBois M, Gilles KA, Hamilton JK, Rebers PA, Smith F. 1956. Colorimetric method for determination of sugars and related substances. Analitical Chemistry, 28(3): 350-356.

Folch J, Lees M, Stanley GHS. 1957. A simple method for the isolation and purification of total lipids from animal tissues. Journal of Biological Chemistry, 226(1): 497-509.

Gogavekar SS, Rokade SA, Ranveer RC, Ghosh JS, Kalyani DC, Sahoo AK. 2014. Important nutritional constituents, flavour components, antioxidant and antibacterial properties of Pleurotus sajor-caju. Journal of Food Science and Technology, 51(8): 1483-1491.

Islam MT, Zakaria Z, Hamidin N, Ishak MABM. 2016a. Characteristics of indoor mushroom cultivation of grey oyster (Pleurotus pulmonarius) by different stages of humidifying treatment. World Applied Sciences Journal, 34(8): 1066-1075.

Islam MT, Zakaria Z, Hamidin N, Mohd Azlan BMI. 2016b. A competitive study on higher yield performance in indoor optimized environment and outdoor cultivation of Pleurotus pulmonarius. MAYFEB Journal of Agricultural Science 2: 1327.

Islam T, Zakaria Z, Hamidin N, Mohd Azlan BMI. 2016c. Optimization of humidifying procedure in controlled environment for indoor cultivation of Pleurotus pulmonarius. African Journal of Biotechnology. 15(45): 2578-2586.

Kadlag GK, Wani PV, Sawant DM. 1998. Comparative performance of different Pleurotus spp. on wheat and green gram straw. Maharashtra Agricultural University, 23(1): 25-86.

Khan MA, Amin SMR, Uddin MN, Tania M, Alam N. 2008. Comparative study of the nutritional composition of oyster mushrooms cultivated in Bangladesh. Bangladesh Journal of Mushroom, 2(1): 9-14. 
Khatun S, Islam A, Cakilcioglu U, Guler P, Chatterjee NC. 2015. Nutritional qualities and antioxidant activity of three edible oyster mushrooms (Pleurotus spp.). NJAS - Wageningen Journal of Life Sciences, 72-73: 1-5.

Leiva FJ, Saenz-Diez JC, Martínez E, Jimenez E, Blanco J. 2015. Environmental impact of Agaricus bisporus cultivation process. European Journal of Agronomy, 71: 141-148.

Lowry OH, Rosebrough NJ, Farr AL, Randall RJ. 1951. Protein measurement with the Folin phenol reagent. Journal of Biological Chemistry, 193(1): 265-275.

Ma Y, Guan CY, Meng XJ. 2014. Biological characteristics for mycelial growth of Agaricus bisporus. In Applied Mechanics and Materials. Trans Tech Publ, pp. 297-302.

Maria EV, Talia HP, Octavio PL. 2015. Edible mushrooms: Improving human health and promoting quality life. International Journal of Microbiology, 2015: 1-15.

Miles PG, Chang ST. 2004. Mushrooms: cultivation, nutritional value, medicinal effect, and environmental impact. CRC Press, Bora Raton, London, New York, Washington DC, pp: 125.

Mizuno T. 1995. Bioactive biomolecules of mushrooms: food function and medicinal effect of mushroom fungi. Food Reviews International, 11(1): 5-21.
Oei P. 2003. Mushroom cultivation: appropriate technology for mushroom growers. Backhuys Publishers, Netherlands, pp: 5065.

Pathmashini L, Arulnandhy V, Wijeratnam RS. 2009. Cultivation of oyster mushroom (Pleurotus ostreatus) on sawdust. Ceylon Journal of Science (Biological Sciences), 37(2).

Sufer O, Bozok F, Demir H. 2016. Usage of Edible Mushrooms in Various Food Products. Turkish Journal of Agriculture-Food Science and Technology, 4(3): 144-149.

Thepa S, Kirtikara K, Hirunlabh J, Khedari J. 1999. Improving indoor conditions of a Thai-style mushroom house by means of an evaporative cooler and continuous ventilation. Renewable energy, 17(3): 359-369.

Turfan N, Karadeniz M, Unal S. 2016. Comparison of some chemical contents of Ganoderma lucidum (Curtis) P. Karst collected from nature and cultured on orange stump. Turkish Journal of Agriculture-Food Science and Technology, 4(3): $158-162$. 